Provided for non-commercial research and education use. Not for reproduction, distribution or commercial use.

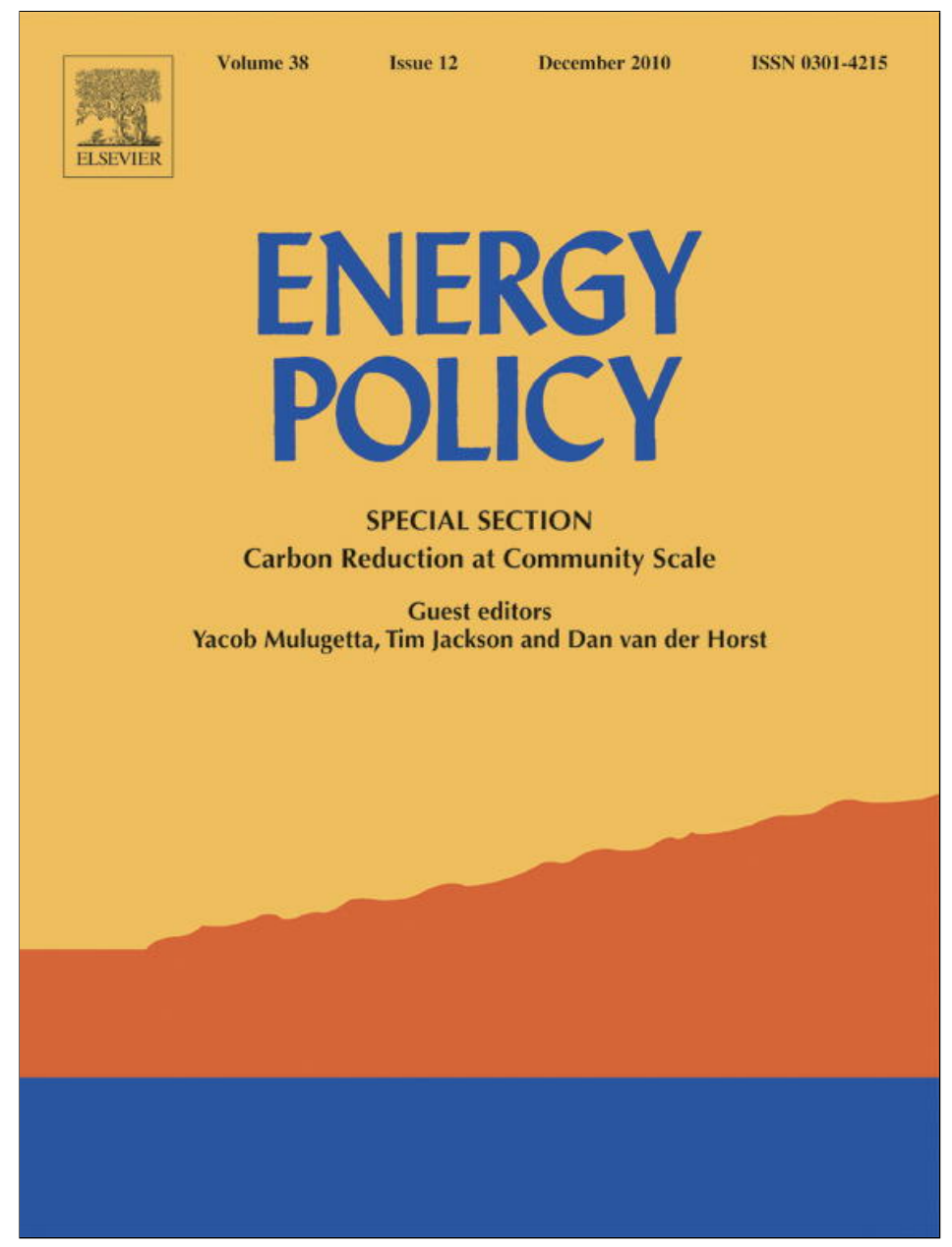

This article appeared in a journal published by Elsevier. The attached copy is furnished to the author for internal non-commercial research and education use, including for instruction at the authors institution and sharing with colleagues.

Other uses, including reproduction and distribution, or selling or licensing copies, or posting to personal, institutional or third party websites are prohibited.

In most cases authors are permitted to post their version of the article (e.g. in Word or Tex form) to their personal website or institutional repository. Authors requiring further information regarding Elsevier's archiving and manuscript policies are encouraged to visit:

http://www.elsevier.com/copyright 


\title{
Community action for sustainable housing: Building a low-carbon future
}

\author{
Gill Seyfang * \\ School of Environmental Sciences, University of East Anglia, Norwich NR4 7TJ, UK
}

\section{A R T I C L E I N F O}

\section{Article history:}

Received 7 January 2009

Accepted 7 October 2009

Available online 14 November 2009

\section{Keywords:}

Sustainable housing

Carbon reduction

Community

\begin{abstract}
A B S T R A C T
This paper presents a new analytical framework of 'grassroots innovations' which views community-led initiatives for sustainable development as strategic green niches with the potential for wider transformation of mainstream society. This framework is applied to a low-carbon, low-impact, community-based sustainable housing initiative in the USA that pioneers straw bale housing techniques within a strong community-building ethos. The project is evaluated according to New Economics criteria of sustainable consumption, and is found to be successful at localising the construction supply chain, reducing ecological footprints, community-building, enabling collective action and building new institutions and systems of provision around housebuilding. However, viewing it as a strategic niche with aim to influence wider society, it is clear that it faces significant challenges in diffusing its ideas and practices beyond the niche. Its model is not necessarily suitable for scaling up or widespread replication; however, the scope for niche lessons to be adopted by mainstream builders is greater, given a supportive policy environment. Recognising the innovative nature of green niches at the policy level could lead to new approaches to governance of bottom-up community action for sustainable development.
\end{abstract}

(c) 2009 Elsevier Ltd. All rights reserved.

\section{Community action for sustainable housing: building a low- carbon future}

People seem to change fundamentally when they gain the added security that comes from knowing they are capable of providing their own shelter. When a community of people posses that confidence and come together to help create one another's homes, it necessarily makes the world a better place to live" (Steen et al., 1994, p. xvi).

Almost half the UK's carbon dioxide emissions come from heating and running commercial and residential buildings, and three million new homes are expected to be built by 2020 (DCLG, 2007a). Given UK government targets of $80 \%$ reductions in carbon dioxide emissions by 2050 (DECC, 2008), there is an urgent need to ensure new and existing homes are more sustainable in terms of both mitigating climate change (reducing carbon emissions), and adapting to the changing climate (DCLG, 2007b; Hacker et al., 2005). There is no shortage of ideas - and practical demonstrations - about how this might be done, from high-tech smart houses which use the latest 'modern' construction methods and carefully monitor and adjust energy use in the home, to more lowtech solutions such as simple off-grid dwellings made of recycled consumer waste, and new social arrangements with shared neighbourhood facilities to promote social capital and cut resource use (Smith, 2007; White, 2002; Fairlie, 1996; Hart, n.d.).

\footnotetext{
* Tel.: +01603 592956.

E-mail address: g.seyfang@uea.ac.uk
}

A substantial sustainable housing movement has developed over the last 30-40 years, pioneering such ideas and experimenting with new practices, but many of their innovations have not been widely diffused. The volume housebuilders responsible for providing the hundreds of thousands of new homes built each year have not adapted many lessons from these green builders. Research indicates that this is due to the co-existence of fundamentally different discourses, practices and governance of sustainability between the mainstream system of housing provision and green builders; consequently the barriers to this transfer of practices encompass ideological, cultural, social, political and ethical factors, as well as economic and technical ones (Smith, 2007; Shove, 1998; Lovell, 2004). The challenge therefore, is to better understand and therefore harness the creative energies of community-led solutions, and adapt them for wider mainstream settings.

This paper addresses that problem by investigating the scope and potential of a previously unresearched sustainable housing initiative, to contribute to building low-carbon, sustainable communities. In so doing, it develops an emerging research agenda around 'grassroots innovations' for sustainable development and applies it to a new empirical case (Seyfang and Smith, 2007; Seyfang, 2008). This agenda argues that the conceptual and policy divide between innovation and community action inhibits our understanding of the innovative potential of grassroots initiatives, and therefore hampers the achievement of innovation and sustainable development policy goals. Innovation for sustainability is a priority for policy and research, as sustainable development requires the decoupling of economic activity from 
environmental impact, while maintaining cohesive, inclusive communities (DEFRA, 2005b). Innovation refers to "the successful exploitation of new ideas", and applies to both technological and social, behavioural change (DTI, 2005). The "transitions management' literature describes the important role of innovative niches in seeding transitions to sustainability in wider social and economic systems, but is rooted in analysis of commercial (often technological) activities in the market economy (Berkhout, 2002; Rip and Kemp, 1998). On the other hand, despite a wealth of community-based action for sustainable development taking place at the local level in the 'social economy' (comprising social enterprise, the voluntary sector and community groups) (DEFRA, 2005a; Church and Elster, 2002), to date the innovativeness of these activities has not been empirically considered. Furthermore, little is known about the nature of, and success factors for the development and diffusion of 'bottom-up' (often social) innovation for sustainability emerging directly from communities (Mulgan et al., 2007). In applying 'transitions management' theory to community-led initiatives, this new approach conceptualises 'grassroots innovations' as innovative niches with the potential for wider societal transformation, and defines them as:

networks of activists and organisations generating novel bottom-up solutions for sustainable development and sustainable consumption; solutions that respond to the local situation and the interests and values of the communities involved. In contrast to mainstream business greening, grassroots initiatives operate in civil society arenas and involve committed activists experimenting with social innovations as well as using greener technologies" (Seyfang and Smith, 2007, p. 585).

In this strategic framework, the benefits of grassroots innovations go beyond the intrinsic social and environmental impacts of their particular niche activities (which may be enhanced as they provide local, contextualised solutions to global problems); they also offer space for the creation of new systems of provision, albeit on a small and experimental scale. These are vertical commodity chains or networks (comprising production, marketing, distribution, retail and consumption in social and cultural context) which mediate between and link "a particular pattern of production with a particular pattern of consumption" (Fine and Leopold, 1993, p. 4).

This space where different values are practiced can be a powerful contrast with mainstream systems, enabling people to visualise a world were everyday practices might be different, and reflecting critically on mainstream provisioning.

In turn, grassroots innovations suffer from intrinsic challenges such as the need for particular skills, characteristics, resources and contexts to both become established and then continue to develop; lack of financial and other resources and institutionalised learning means that organisations are often ill-equipped to cope with financial and political shocks, and poorly prepared to make the most of opportunities for greater influence. Finally, there are challenges related specifically to the diffusion of grassroots innovations, namely that their small scale and rootedness makes them difficult to scale up and replicate, and their ideological basis can result in value clashes with mainstream settings, resulting in difficulty transferring ideas and practices (Fine and Leopold, 1993). If the surrounding regime is a mainstream policy framework for sustainable consumption then the niche's discourse and practice must represent an alternative vision for sustainability. Here one particular alternative perspective is presented as a 'New Economics' approach to sustainable consumption (see below).

This paper first sets out the scientific and policy rationale for sustainable housing, and then the context and historical development of the sustainable housing movement in the UK is considered. Following this, the mainstream and New Economics approaches to sustainable consumption are described, and a set of criteria for evaluating the characteristics, objectives and effectiveness of sustainable consumption initiatives is derived. This theoretical framework is then applied to a new empirical case study. The community-led project discussed here - straw bale building, pioneered by the US-based Canelo Project - represents a range of low-impact, low-energy socio-technical systems, which although viable, celebrated and influential, remain marginal. This established US-based exemplar case study offers important lessons for the newly emerging UK movement, and has materially shaped the UK's straw bale community, as shall be explained below. Finally, the paper discusses the scope for these ideas and examples to spread from their green niches to influence wider mainstream practices, by examining three potential routes for innovation-diffusion: replication, scaling up and translation to mainstream settings. The paper concludes by presenting some implications of this study for policy and research.

\section{The rationale for low-carbon housing}

The imperatives of climate change mean that our building technologies need to evolve to meet the demands of climate change predictions, while simultaneously reducing the contribution they make to $\mathrm{CO}_{2}$ emissions. Housing plays a significant part in the UK's emissions profile (DCLG, 2007a). In 2005, 27\% of the UK's $\mathrm{CO}_{2}$ emissions (around 150 million tonnes a year) were attributed to heating, lighting and running domestic buildings; of this, almost three-quarters comes from space and water heating, and while appliances and lighting accounts for only around $22 \%$ of domestic emissions, current trends are for this to rise with new technologies such as digital radios, plasma TVs and air conditioning requiring higher energy inputs (DCLG, 2007a). In 2007, the UK's Department for Communities and Local Government published its blueprint for new housing over the coming 15 years entitled 'Homes for the Future: more affordable, more sustainable' (DCLG, 2007b), and an accompanying policy statement 'Building A Greener Future' (DCLG, 2007a). It identifies a growing housing shortage in the UK, caused by a combination of falling housebuilding rates, and rising numbers of households, many of them single-person households. The report sets out housebuilding targets of two million new homes by 2016 and a further million by 2020 , but stipulates that homes must also become more energy efficient to meet the UK government's new targets for reducing $\mathrm{CO}_{2}$ emissions by $80 \%$ of their 1990 levels by 2050 (DECC, 2008). In the UK, while only around $1 \%$ of homes are built each year, by 2050 up to a third of the UK's homes will have been built since the present day, and "we need a revolution in the way be build, design and power our homes" (DCLG, 2007b, p. 9). Therefore, in conjunction with its voluntary Code for Sustainable Homes (DCLG, 2008), the UK government aims to set progressively higher emissions-reduction targets through its building regulations, and so encourage improved standards in new-build housing, to achieve 'zero-carbon' homes by 2016 (this is defined as zero net carbon emissions from all energy use in the home over a year, and applies at the level of the development, not the individual home, and at present does not permit offsetting to achieve the targets (DCLG, 2007a)).

There are social and economic, as well as environmental drivers for sustainable housing. Energy prices have raised dramatically in recent years, with average UK household gas bills rising by $109 \%$ and electricity bills by 70\%, between January 2003 and March 2008, with average annual household fuel bills amounting to $£ 1060$, resulting in a rise in fuel poverty. Energyrelated indebtedness (measured in terms of consumers owing 
more than $£ 600$ on their utility bills) has risen sharply in line with these increases: between 2004 and 2007 it rose by 64\% for electricity consumers and by $19 \%$ for gas customers (Energywatch, 2008). At the same time, water supplies have been stressed in south-eastern England in particular (due to high population density, high levels of water use, increase in households and low rainfall), and across the UK water and sewerage prices have risen accordingly at above-inflation levels (see www.ofwat.gov.uk). Borrowing the language of carbon neutrality, the UK government is implementing measures to promote 'water neutrality' in areas of new development to offset the water resource impacts of building new housing, with water conservation efforts such as rainwater harvesting, water conservation and metering. The aim is that the total water demand is unchanged after the development (Environment Agency, 2008).

Projections for the future indicate that these trends will worsen. Climate change is expected to bring more periods of extreme hot weather in summer, with peak summer temperatures up to $7^{\circ} \mathrm{C}$ higher by the 2080s than today, and the summer 2003 European heatwave when temperatures reached $38^{\circ} \mathrm{C}$ in the UK for the first time, would become the norm (Hulme et al., 2002). Given these changing conditions, the buildings we live and work in may not be able to cope with extreme high temperatures in the summer. In the UK air conditioning is becoming normalised in workplaces, particularly in the south of England, to maintain thermal comfort and their use is predicted to spread to domestic buildings over the next few decades. A recent modelling study found that in traditional 19th century terraced houses, and 1960sbuilt houses, the reduced need for heating over the next 80 years is offset by increased energy use for air conditioning, resulting in overall increases in emissions of $30-40 \%$ by the 2080s (Hacker et al., 2005). These calculations point to the need to retro-fit existing building, and design new ones in ways which do not rely on air conditioning to maintain thermal comfort, but rather draw on cooling socio-technologies traditionally employed in warmer climates, such as shading from the sun, thermal mass to stabilise temperature, passive heating and cooling systems and afternoon siestas (Hacker et al., 2005; SDC, 2006).

\section{Building a sustainable housing movement}

While there is clearly an urgent need for new technologies and designs, it is also true that there are many technologies already in use, albeit on a small scale, which can deliver low- or zero-carbon homes, and some of these form the focus of this paper. Many are descended from an earlier wave of sustainable housing activism and development, prompted by the 1970s environmental movement and the 'Limits To Growth' hypothesis (Meadows et al., 1972), and later boosted by the push for greater energy efficiency and energy security prompted by the 1970s oil crises. Smith explains:

The founding concerns of eco-house builders in the early 1970s were informed by the way existing house-building methods, technologies and services were wasteful of materials and energy, dependent upon finite sources for those materials, and highly polluting. The principle of 'autonomy' was developed in contrast to the incumbent regime" (Smith, 2007, p. 436).

These eco-housing pioneers drew inspiration from Schumacher's 'Small Is Beautiful' (1993, first published in 1973) and his concept of 'appropriate technology', i.e. adopting a scale and complexity of technology appropriate to its setting, and similarly were concerned with the effects of housing on human health and spirit. To meet the demands of householders wishing greater selfsufficiency from expensive and potentially unreliable energy supplies, this meant generally low-tech solutions which could be self-managed to create 'natural' homes which "support personal and planetary health" (Pearson, 1989, p. 12). A grassroots sustainable housing advocacy movement was formed, comprising activists, builders and academics, who shared many of the New Economics values of human-scale development, self-reliance, decentralisation and empowerment (Smith, 2007). Their activities tended to emphasise renewable material and energy sources, lowpolluting materials, a concern with the overall lifetime impacts of the house (i.e. occupation impacts as well as construction impacts) and autonomy. In particular, the experimental niche nature of much of this development lent itself to self-build by owner-occupiers, in contrast to the mainstream housing market where speculative mass-produced housing is the norm. The Centre for Alternative Technology was established in Wales in 1973 as a test-bed and showcase of renewable energy and appropriate technologies, community living and self-sufficiency. It later turned to public education and outreach as a means of spreading its ideas and lessons, and is still running extensive visitor programmes today, albeit in a quite altered mainstream context which now considers renewable energy as cutting-edge and desirable, rather than counter-cultural (see www.cat.org.uk).

During the 1970s much progress was made through experimentation and technological development for the duration of the energy crises; but once oil supplies returned to normal and the financial incentive for radical energy efficiency was removed, the movement largely lost the attention of mainstream builders and government. Nevertheless, development of sustainable housing continued during the 1980s and 90s. Vale and Vale (2000) define 'green architecture' as design which: conserves energy, works with climate, minimises use of new resources, respects its users and its site and is holistic. Their proposals for an Autonomous House were realised and showcased as the first such self-sufficient residence built in the UK, purposely designed to look like a 'normal' house, it nevertheless demonstrated radical principles of self-sufficiency through energy generation, water harvesting and sewage treatment, and was not connected to mains utilities. Its design also capitalised on solar gain by using large south-facing windows to warm the house during daylight and heavy ('thermally massive') walls and floors to store the heat and return it overnight, thereby significantly reducing the need to heat and cool the living space (known as passive heating and cooling). Vale and Vale subsequently worked on the Hockerton Housing Project, a celebrated development of five autonomous earth-sheltered houses that have been found to use less than a quarter of the energy of a conventional house (Energy Saving Trust, 2003). Another leading light in this movement was the Findhorn Foundation's eco-village in Scotland, founded first as a spiritual centre in the 1960s, then developed as a demonstration site for green building and sustainable living from the mid-1980s onwards. With over 50 eco-buildings it now houses around 350 people, and continues to offer educational courses, while also providing a hub for the eco-village movement through founding the Global Ecovillage Network, holding major conferences in sustainable living, community and ecological design (Conrad, 1995; see also www.findhorn.org).

In addition to experimentation with building designs and energy systems, there has been a resurgence of interest in traditional building materials which could be locally sourced from renewable or recycled materials such as straw bale, wood, cob (mud and straw mixtures), reed and thatch, as well as alternative formulations of concrete using natural materials such as 'papercrete' and 'hempcrete' (see for example Steen et al., 1994; Pearson, 1989; Hart, n.d.). Accompanying this has been a growth in social innovation such as housing cooperatives and co-housing (a type of community-based living where residents have their 
own homes and share some facilities such as laundry, a community hall and gardening), intentional communities and communes (see White (2002) for a recent overview of UK sustainable housing schemes in the UK, listing 81 exemplar projects ranging from low-energy single-household homes to large community self-build projects and eco-visitor centres).

With the advent of action to tackle climate change, ecohousing has become headline news again. In terms of the current policy agendas, sustainable housing is now primarily understood to mean 'energy-efficient' or 'low-carbon' housing. Lovell (2004) describes how the earlier 'advocacy coalition' of like-minded activists with shared deep-green values has been replaced by a 'discourse coalition' of actors with quite different perspectives on sustainable housing (e.g. eco-housing developers and mainstream housebuilders), but whose interests overlap on the topic of 'lowcarbon' housing. For the latter, sustainable housing is about technology-intensive 'smart' housing which requires no change in householders' behaviour to deliver energy savings. The types of technologies employed might include movement-sensor lights, energy-efficient appliances and networked devices to 'intelligently' respond to residents actions (Lovell, 2004).

At the other end of the scale is 'low-impact' development, a term employed by grassroots builders concerned with minimising their ecological footprints, defined as development which:

is temporary; is small-scale; is unobtrusive; is made from predominantly local materials; protects wildlife and enhances biodiversity; consumes a low level of non-renewable resources; generates little traffic; is used for a low-impact or sustainable purpose; is linked to a recognised positive environmental benefit" (Fairlie, 1996, p. 55).

Fairlie acknowledges that most buildings will not meet all these requirements, but argues that any truly low-environmentalimpact development (as opposed to low-landscape-impact for instance) will conform many of the criteria. Examples include temporary dwellings such as yurts, tipis and benders (tent-like structures made of bent and woven poles covered with canvas), as well as more permanent houses insulated with straw bales and cob-built houses (Fairlie, 1996). While these are extreme examples, they do demonstrate - as do all the grassroots innovations discussed here - that another way is possible, and that simple livelihoods can be obtained and managed in some unlikely locations-in woodlands, for example, or tending smallholdings, and without the need for high-capital investment property or high incomes to service mortgages and utility bills. A current exemplar of such development is Ben Law's wooden house in West Sussex, which was the subject of TV documentary Grand Designs. The house cost $£ 25,000$ and was self-built from chestnut and other materials obtained in Law's private woodland in which it sits, is self-sufficient for energy, water and waste and a model marriage of low-impact design and lifestyle (Law, 2005; see also www. ben-law.co.uk). Another is Tony Wrench's off-grid wooden roundhouse built in the Pembrokeshire National Park in Wales, built for $£ 3000$ from local natural materials and providing a sustainable rural farm livelihood, but the subject of a protracted planning battle (Wrench, 2001; see also www.thatroundhouse.info). This type of extremely low-impact housing tends to fall foul of planning regulations, both in terms of the construction of the dwellings, and the locations where people wish to build them. However, according to Simon Fairlie, a prominent writer in the field, this type of development is so sustainable - and has such a low ecological footprint - as to be sufficient justification for a new category of planning law, permitting low-impact development in rural areas to support sustainable livelihoods in the countryside. The next section explores this issue of sustainability with reference to mainstream and alternative models of sustainable consumption.

\section{A new economics approach to sustainable consumption}

In 2003, the UK Government announced its strategy for sustainable consumption and production which it defines as "continuous economic and social progress that respects the limits of the Earth's ecosystems, and meets the needs and aspirations of everyone for a better quality of life, now and for future generations to come" (DEFRA, 2003, p. 10). This was a precursor of the UK government's Sustainable Development Strategy, which quietly dropped the explicit imperative for economic growth which had been present in its earlier strategy (DETR, 1999) and replaced it with a guiding principle of achieving a "strong, stable and sustainable economy" and a call to move towards a "one planet economy" (HM Government, 2005, p. 16, 43). But in practice, the policies and tools proposed were much the same with an emphasis on decoupling economic growth from environmental degradation, to be achieved through a range of marketbased measures, and calling on informed and motivated citizens to use their consumer sovereignty to transform markets by demanding improved environmental and social aspects of production and product design (HM Government, 2005). Importantly, this consumer behaviour change aspect of the strategy relies heavily on a cognitive (information-processing) approach to changing behaviour which has its roots in neo-classical economics, and only recently has a more sophisticated - but nevertheless individualistic - psychology-based social marketing perspective been formally adopted (DEFRA, 2007a). This mainstream policy approach to sustainable consumption has been criticised - not least by the government's own Sustainable Development Commission - on the basis of a number of significant factors which critics claim limit the effectiveness and scope of such a strategy (Porritt, 2003). These include market failures, category errors, disenfranchisement and inequity, and at heart, an inability to address the fundamental problem: "How can consuming more of anything help us save the planet? The point is to consume less-and no one's going to make any money from that" (Lynas, 2007, p. 5). Critics, therefore, conclude that the mainstream approach is limited in scope, flawed in design and unjust in its objectives. (Maniates, 2002; Sanne, 2002; Seyfang, 2004a, 2005; Southerton et al., 2004; Burgess et al., 2003).

An alternative theoretical approach to environmental governance and sustainable consumption is proposed by a broad body of thought known collectively as the 'New Economics' which combines ecological economics, institutional economics, political economy and behavioural economics (Ekins, 1986; Henderson, 1995; Daly and Cobb, 1990; Boyle, 1993). The New Economics is an environmental philosophical and political movement founded on a belief that economics cannot be divorced from its foundations in environmental and social contexts, and that sustainability requires a realigning of development priorities away from the primary goal of economic growth towards well-being instead (Jackson, 2009). It also stresses the benefits of decentralised social and economic organisation and local self-reliance in order to protect local environments and economies from the negative impacts of globalisation (Jacobs, 1984; Schumacher, 1993). Fundamentally, it adopts a 'Spaceship Earth' view of the environment, namely that resources are finite, and functioning ecosystems are critical for our survival, and this must be the framework within the economy operates. Although its traditions go back much further (Lutz, 1999), the UK's New Economics Foundation was founded in 1986 to promote these ideas in research and policy (Ekins, 1986). At the same time, theorists such as Jackson 
(2007), Ekins (1986), Max-Neef (1992), Douthwaite (1992) and O'Riordan (2001) were pursuing these ideas within the academic world, for instance by developing new measures of well-being, seeking to understand consumer motivations in social context, and debating how an 'alternative' sustainable economy and society might operate. By suggesting that societal systems of provision be examined, redesigned and reconfigured in line with sustainable consumption goals, the New Economics proposes nothing less than a paradigm shift for the economy, or a wholesale transition in the presiding socio-technical systems. This implies that rather than making incremental changes, the model entails a widespread regime change for the economy and society, altering the rules of the game and the objective of economic development.

Unsurprisingly perhaps, this eclectic body of thought rejects economic individualism, and pays particular attention to the sociological and contextual - social, psychological and structural - factors which influence consumption practices. For example, whereas the mainstream approach to sustainable consumption relies on 'green consumers' playing their part in the marketplace, the New Economics instead addresses 'Ecological Citizens' who act ethically in public and in private to reconfigure the patterns of their lives to reduce environmental and social impacts on others (Dobson, 2003). Where the mainstream model uses economic rational-actor theories of consumption, the New Economics draws on sociological insights into cultural determinants of behaviour, routines, norms, habits and meaning-construction. Its ontological subject is not the individual, but rather the holistic socio-economic-technical system within, and as such it is concerned with altering practices - sets of behaviours which collectively confer meaning onto actions, and which are shaped in turn at the macro and meso levels of society (Shove, 2004; Røpke, 2009). It is fundamentally an equity-based understanding of environmental governance, drawing on 'ecological footprinting' metaphors to guide action. Ecological footprints define and visualise environmental injustice in terms of the inequitable distribution of 'ecological space' (the footprint of resources and pollution-absorbing capacity) taken up by individuals, cities and countries; this inequity requires a reduction in the scale of material consumption among the affluent advanced economies (Wackernagel and Rees, 1996).

The New Economics presents many challenges to mainstream thought and practice on sustainable consumption (for a comparison between the two approaches, see Table 1); its objectives are to develop a practical approach to sustainable development which encompasses new definitions of wealth and work, new uses of money and which re-integrates ethics of justice and equity into economic life, and thereby to provide ecological citizens with the means to express their values and reduce their ecological footprints. It champions the active ecological citizen rather than the green consumer, placing at centre stage actors "able to vote with more than their feet in support of collective projects like those of environmental reform, [and] who have a hand in shaping options as well as exercising choice between them" (Shove, 2004 , p. 115, 116). The New Economics aims to deliver this through shifting the trajectory of economic development towards an alternative goal of sustainable well-being, and enabling the emergence of a range of new socio-technical systems of provision (comprising technology, social relationships, regulatory frameworks, social norms and routines) based on these values. Its theories of behaviour change are pluralistic: its strategies incorporate simple cognitive behaviour-change incentives, as well as responses to more complex psychological contexts and sociological structures, but throughout this body of thought is a fundamental recognition that existing infrastructures of provision are not fit for purpose (in contrast with a mainstream view that sees them as merely requiring reform). As such, it aims to trigger, enable and support a series of socio-technical transitions in mainstream regimes, each of which is comprised of interrelated technologies, institutions, norms, cultures and expectations. This process is discussed in-depth below, but here the task is to consider what such changes might look like in practice: in other words, how should New Economics initiatives for sustainable consumption be evaluated?

Despite a growing number of practical applications of this model, there is a paucity of robust empirical research to test the ideas of this New Economics approach, and there has to date been no systematic means of evaluating activities to assess their contribution to sustainable consumption. To meet that need, therefore, a new qualitative evaluation framework is presented which is designed to incorporate the key elements of the New Economics vision of sustainable consumption, and builds on the theoretical foundations outlined above. A New Economics strategy for sustainable consumption would therefore embody the following five characteristics: localisation, reducing ecological footprints, community-building, collective action and building new infrastructures of provision. This set of indicators forms the basis of a multicriteria evaluation tool for sustainable consumption, which is applied to the initiative examined below.

\section{Evaluating grassroots sustainable housing initiatives}

Having reviewed the policy and research contexts of sustainable housing, attention now turns to practice. This section moves on from general discussions of sustainable housing to examine a practical initiative in more detail. It draws on fieldwork conducted

Table 1

Comparing mainstream and new economics models of sustainable consumption.

\begin{tabular}{|c|c|c|}
\hline & Mainstream model of sustainable consumption & New economics model of sustainable consumption \\
\hline $\begin{array}{l}\text { Environmental } \\
\text { context }\end{array}$ & Frontier economy & Spaceship Earth \\
\hline Objective & $\begin{array}{l}\text { Incremental improvements in resource efficiency; continual } \\
\text { economic growth through 'consuming differently' }\end{array}$ & $\begin{array}{l}\text { System-wide changes in infrastructures of provision to reduce } \\
\text { absolute consumption levels by 'consuming less' }\end{array}$ \\
\hline Mechanism & $\begin{array}{l}\text { Sustainable consumers send market signals for sustainably } \\
\text { produced goods and services, which drives innovation and } \\
\text { improvement }\end{array}$ & $\begin{array}{l}\text { Collective action reshapes socio-technical infrastructures of } \\
\text { provision, creating new systems and non-market alternatives } \\
\text { where necessary }\end{array}$ \\
\hline Consumers & Individual green consumers & $\begin{array}{l}\text { Ecological citizens within communities of place, practice and } \\
\text { interest }\end{array}$ \\
\hline $\begin{array}{l}\text { Progress measured } \\
\text { by }\end{array}$ & $\begin{array}{l}\text { Traditional measures of economic growth; consumption as a proxy } \\
\text { for utility (happiness) }\end{array}$ & $\begin{array}{l}\text { New measures of sustainable well-being; consumption not } \\
\text { necessarily related to well-being }\end{array}$ \\
\hline \multirow{2}{*}{$\begin{array}{l}\text { Theories of } \\
\text { consumption }\end{array}$} & Economic & Economic \\
\hline & Psychological & $\begin{array}{l}\text { Psychological } \\
\text { Sociological }\end{array}$ \\
\hline Examples & $\begin{array}{l}\text { Green and ethical consumerism; corporate greening of global } \\
\text { capitalism; social marketing }\end{array}$ & $\begin{array}{l}\text { Local provisioning e.g. farmers' markets; mutual aid e.g. LETS; } \\
\text { self-reliance e.g. low-impact development }\end{array}$ \\
\hline
\end{tabular}


in 2004 with the Canelo Project, grassroots innovators of sustainable housing in the USA and emblematic actors in the sustainable housing movement. The fieldwork consisted of a site visit and participant observation over several days, residing on site and sharing meals and leisure time with the Steen family. During this time, the Canelo Project founders demonstrated and explained many aspects of their vision, motivations and work, and I observed first-hand the results of their labours. In-depth semistructured interviews were conducted, and documentary analysis (their books, website and other literature) provided more contextual information. Quotations are from personal interviews, unless otherwise referenced.

The low-impact sustainable housing movement in the USA is, in some aspects, considerably further advanced and established than its UK counterparts. Consequently, the rationale for studying practice in the USA is to learn from pioneers whose ideas are developing ahead of UK experience (due to a range of cultural, regulatory and climatic factors which are discussed later on), and are beginning to spread to the UK through the formation of international niches. The case study examined here is, as shall be discussed below, a key actor in this international movement, and has directly influenced the UK's low-impact housing movement, with ongoing reciprocal links. This allows us to assess the initiatives on the basis of a greater breadth of experience than UK comparators would allow, and investigate potential future opportunities and challenges in the UK context. This initiative represents innovations for sustainable consumption that move beyond the technical, to examine the need for fundamental changes in values and behaviour, in developing eco-housing. The analysis concentrates as much on the individuals behind the movement as on the technical aspects of their building approaches, and uses the empirical, personal and contextual data obtained to make conjectures about the importance of social and cultural contexts in forming, developing and extending from green housing niches. Indeed, these are shown to be deeply embedded in their social and cultural contexts, and the practical demonstrations they have achieved are tied intimately into the specific circumstances and lives of their advocates. In examining the impacts of this initiative, the five New Economics criteria of sustainable consumption developed above are returned to, namely the potential for localisation, reducing ecological footprints, community-building, collective action and building new infrastructures of housing provision. Findings are summarised in Table 2.

\subsection{The Canelo Project}

Leading proponents of the US straw bale housing movement, Athena and Bill Steen founded the non-profit Canelo Project in
1990 to further their experimental and educational work. Their seminal book 'The Straw Bale House' (Steen et al., 1994) consolidated the then-emerging contemporary interest in straw bale building among environmentalists keen to develop low-cost, energy-efficient buildings from natural, local materials, and inspired a growing movement in the US and around the world, with its practical advice, technical know-how and building plans. Further publications celebrate the beauty and diversity of applications of simple hand-built straw-and-clay construction and decoration techniques, and the vernacular of self-built shelter around the world (Steen and Steen, 2001; see also www. caneloproject.com). Canelo is located in southern Arizona, in the south-west United States, set among oak woodlands and high desert. The project aims to develop "ways of living that connect us to others and the natural world" through "an ongoing exploration of living, growing food and building that creates friendship, beauty and simplicity" (Canelo Project, n.d.). The 40-acre site holds the Steens' traditional adobe family home, an adobe guesthouse for visitors, and a dozen or so small straw bale buildings used as accommodation and storage sheds, which have been constructed by participants of straw bale construction and plastering residential workshops, and are evidence of evolving techniques and expertise. In addition, the Canelo Project works across the border in Mexico with local communities, teaching simple self-build techniques to enable groups of women to build each others' houses for around $\$ 500$ each, and constructing a demonstration office building for NGO Save The Children in Cd. Obregon (Canelo Project, n.d.).

These houses use bales of straw (an agricultural waste product) as large building bricks for the outer walls, which are then plastered with adobe (earth plasters). They are highly insulative, made entirely of local, natural, cheap materials and are easy to work with, enabling wide participation in the building process. Straw bale structures can be load-bearing (i.e. the roof sits directly on bale walls), or the bales can be used as in-fill between the props of a wooden-framed building. Often the earthen plasters of interior walls and floors are highly polished, creating a waterproof, marble-like finish. Straw bale can be used as simply a technical wall system in a mainstream house, offering greater thermal comfort and energy efficiency, or it can represent a more sustainable way of living, suggesting a hand-sculpted, humanscale building, putting its owners more in touch with nature. The Canelo Project takes this latter approach, favouring the empowerment of small, cheap and simple self-build, over the mainstream, impersonal and industrial-scale construction techniques. This type of building is well-suited to the desert climate, but simple adaptations to different climates can include termite/rodent barriers, stone foundations and overhanging roofs to reduce

Table 2

Evaluating sustainable housing initiatives as a tool for sustainable consumption: key findings.

\begin{tabular}{|c|c|c|}
\hline \multicolumn{2}{|l|}{$\begin{array}{l}\text { Sustainable consumption } \\
\text { indicator }\end{array}$} & Canelo Project \\
\hline & & $\begin{array}{l}\text { Leading proponents of straw bale housing movement in the USA. Nonprofit organisation offering educational courses, } \\
\text { demonstration projects and range of 'how-to' books. Favours self-build for the connection it offers between home and inhabitant. } \\
\text { The process is at least as important as the outcome }\end{array}$ \\
\hline Localisation & $\hat{2}$ & Construction materials are principally straw and mud, widely available and free in many parts of the world. \\
\hline $\begin{array}{l}\text { Reducing ecological } \\
\text { footprint }\end{array}$ & है & $\begin{array}{l}\text { Strong commitment to a globally equitable distribution of resources, hence advocates simple low-consumption living in the } \\
\text { developed world. Very low ecological footprints of straw bale housing, both in construction and use through higher energy } \\
\text { efficiency and thermal stability }\end{array}$ \\
\hline Community-building & है & $\begin{array}{l}\text { Low-cost, inclusive and accessible construction techniques, community-building (barn-raising), women and children involved too. } \\
\text { Community-building is major impact of this type of housebuilding. "Connecting people, culture and nature", building supportive } \\
\text { networks }\end{array}$ \\
\hline Collective action & ध & $\begin{array}{l}\text { Small-scale activities, but with a strong sense of acting collectively such as through community-build projects, and empowering } \\
\text { people within these groups }\end{array}$ \\
\hline New social infrastructure & ही & Offers a system of housing self-provision which bypasses industrial construction techniques and technologies \\
\hline
\end{tabular}


rainfall on the outer walls (Steen et al., 1994). Common concerns about strength, fire-safety and waterproofing of straw bale buildings are generally unfounded, and plastered straw bale buildings have been known to last 50-100 years.

The Canelo Project is clearly a pioneering grassroots initiative working towards sustainable consumption through research, experimentation, innovation and diffusion of lessons about straw bale construction techniques. But as the following analysis of their sustainable consumption impacts shows, theirs is much more than a technical contribution. There is a strong ecological citizenship rationale to this initiative.

To assess the Canelo Project's contribution to sustainable consumption, the evaluation criteria outlined above are used. First, the emphasis on using locally available materials (mud and straw) for construction is a significant localisation impact of this type of building approach, quite distinct from mainstream building techniques. In addition, the Canelo Project's techniques and processes are adapted according to local cultures, materials and skills. For instance, in Mexico an earthen floor was associated with poverty, so the polished adobe floors were often concreted over. By emphasising the creativity and artistic techniques possible with earthen plasters, the material was given higher status and became more widely accepted. In addition, new recipe mixtures of mud and straw were developed to better suit the skills and tools available in different situations. Second, these building techniques imply a significantly reduced ecological footprint, principally through using natural, biodegradable carbon-neutral materials, avoiding highly polluting materials such as cement, and then from providing greater insulation than conventional housing, so reducing energy requirements for heating and cooling throughout its life. In addition, the Project's ecological citizenship aims are to enable people to reduce their consumption levels and live simpler, more community-oriented lifestyles, more in keeping with an equitable distribution of resources. The rationale for straw bale building was originally environmental - to reduce waste and energy use - and the Steens retain a keen awareness of the Canelo Project's role in enabling people to live equitably and comfortably within a 'fair share' of the world's resources - in other words, a much-reduced consumption level for the developed world. Bill Steen explains: "when people get a take on green buildings in this country, we don't think beyond our borders - we don't look at the global picture - we don't stop to say 'how much materials are there to go around?"'; he mentions that there are plenty of examples of high-consumption unsustainable straw bale houses, which are "totally unfair in terms of their size and the materials used."

Third, the Canelo Project has powerful community-building impacts through its emphasis on low-cost, affordable materials and inclusive techniques. The building system is inherently open to low-income and socially excluded groups. The hand-building technique using natural materials and little specialised labour lends itself to wider participation in building than is the norm when specialist skills and industrial tools and materials are used: "People who might otherwise be excluded become directly and enthusiastically involved" (Steen et al., 1994, p. 21). The Project's Mexican constructions were typified by women working barefoot and children playing around the site, mixing clays and mudding the bales and communities coming together for bale wall-raisings over a day or two, with opportunities for social interaction and mutual support. From their perspective, straw bale buildings can be sustainable, but they are not necessarily so, and it is the process of building, in relationship with nature, the materials and with other people, that makes a building sustainable. In fact, as their work has progressed it has become the social and community aspects of straw bale building which have become more prominent and valuable to the Steens. Fourth, and related to this point, the particular model promoted by the Canelo Project is one of collective action rather than an individualism. Athena Steen stated:

There are other ways to build which are possible when you come together, than when you build by yourself. What's possible is magic. It's not always about the building, it's about building people, and communities and relationships to nature. It was a vehicle for bringing people together, the building itself was a by-product.

In other words, the socio-technical innovation the Canelo Project promotes is structurally designed to facilitate collective effort in preference to atomised construction. Finally, it is clear that the Project's approach to construction represents a fundamentally different system of housebuilding to the mainstream, and so develops new infrastructures of housing provision. It uses widely accessible and affordable techniques and materials, involves women and children in the building process, is suited to individual and community self-build, and aims to empower people to create their own low-cost environmentally sound shelter.

\section{Diffusing the benefits of sustainable housing niches}

The process of building with bales includes the possibility of making a profound change in the fabric of human societies around the world. In fact, this vision is not exclusively a matter of straw bales; the questions we are trying to pose ... are basic: how do we build, and how does that process occur in relation to the community and to the life around us? Straw bales happen to be a material that has inspired many to look at the process of building in a different light" (Steen et al., 1994: xvi).

The sustainable housing initiative examined above represents a very particular, New Economics perspective on green buildings. It is a bottom-up, value-led innovative organisation, founded by individuals following a social and environmental vision. It practices and promotes a new system of housing provision, embodying socio-technical arrangements which differ from mainstream building practices in the developed world. It can be seen as a green sustainable housing niche, different in many dimensions to the mainstream, emerging from grassroots community activism, and aiming not only to thrive as a niche, but also having a strategic goal to influence the wider socio-technical regime.

The potential for this diffusion of niche ideas and practices is examined, with reference to The Canelo Project. Smith describes the ways in which "green niches are constructed in opposition to incumbent regimes. They are informed, initiated and designed in response to sustainability problems perceived in the regime" (Smith, 2007, p. 436), and they therefore have little compatibility with the mainstream system of provision. As a result, sustainable housing niches have little linking potential and growth prospects across all the socio-technical dimensions: guiding principles, technologies and infrastructure, industrial structure, user relations and markets, policy and regulations, knowledge base and cultural meanings (Smith, 2007, p. 429). This distinctiveness is evident with the sustainable housing project discussed here, and as the previous section has outlined, the characteristics of these niches which distinguish their system of provision from the mainstream are manifold. They advocate a small scale, affordable, self-build approach to housebuilding; use local, natural and recycled materials in inclusive and creative construction processes; they reduce consumption in building and inhabitation with highly energy-efficient designs and low-carbon technologies; they make explicit the consumption patterns and resource use 
which are otherwise inconspicuous, and challenge the accepted wisdom of centralised power and water supply; and they embody ecological citizenship principles, offering a route to an alternative lifestyle: Athena Steen of the Canelo Project explains: "People are becoming fed up with things the way they are, they are looking for a change. Somehow straw bale holds that for people, it is a symbol of something different." Of course, green housing niches do not exist in a vacuum; they have complex interactions with the mainstream regime, for better and for worse. Given the incompatibilities between the green niches and the regime, how have the Canelo Project fared in their efforts to spread their ideas and transform mainstream building practices? This diffusion of knowledge and practice can take three routes, namely replication at the same scale, upscaling and translation of ideas to the mainstream regime; these are examined in turn.

The main way sustainable housing niches have grown to date has been through the replication of individual buildings, multiplying the base of green buildings at the same owner-builder scale, allowing for bespoke designs and adaptations as construction takes place alongside learning and experimentation. Concurring with the 'innovative niche' perspective of grassroots initiatives, the Canelo Project is active in straw bale innovation, learning and experimentation, in particular through the development of new techniques with earthen plasters and decorative clays, as well as structural and technical developments. In addition to this development-within-the-niche, replication of the Canelo Project's work has occurred through publication of books and articles explaining their rationale and providing technical know - how for the self-builder, and also through educational courses offering hands - on experience with these unfamiliar building techniques. These methods have been successful in spreading ideas, best practice and lived experience among committed green builders and individuals searching for an alternative way of life. And this approach is slowly growing the movement across the world. In the UK, the leading straw bale proponents are 'Amazon Nails' a social enterprise working towards mainstream adoption of straw bale building techniques, disseminating best practice and training community groups and construction professionals in low-impact design and construction. They have been involved with over 50 projects in the UK, some with full planning permission and building regulations approval (others are used as sheds, animal shelters, etc.), and estimate that from the UK's first straw bale building built in 1994, by 2001 the UK had approximately 70 such buildings in use (Amazon Nails, 2001). This initiative was formed after its founder visited the Canelo Project for a residential straw bale construction workshop, and returned to the UK inspired to spread the ideas and practice. In turn, the Steens visited the UK in 2009 for a UK tour of exemplar straw bale buildings organised by Amazon Nails. In this way, the niche grows and diffuses, spreading best practice and inspiration through the actions and movements of key actors.

Although it is possible to obtain planning permission building approval for straw bale buildings in the UK (see Amazon Nails, 2001), the unfamiliarity of local planning offices with the concepts make each application a laborious and potentially offputting task for the green self-builder, and can prevent very lowimpact buildings being developed at all in rural areas (see earlier discussion). Indeed, one of the main barriers facing green sustainable housing niches is posed by planning regulations and building standards which were not designed with these building methods in mind. In their study of autonomous sustainable housing, Van Vliet et al. found that "new modes of provision can be limited by regulatory frameworks designed for public provision and infused with certain notions of what constitutes a safe and efficient method of supply" (Van Vliet et al., 2005, p. 93). Moreover, to the extent that this strategy relies on the continual recruitment of committed environmentalists, and ecological citizenship is a niche value, the scope to continue growing in this manner is limited in terms of numbers. Compounding this limitation is the fact that mainstream framings of eco-housing "continues to focus predominantly upon technical and economic aspects, whilst overlooking the social processes and guiding principles underpinning those developments" (Smith, 2007, p. 437). The specific circumstances which give rise to these green socio-technological niches relate to geography, climate, personality, economics, culture, politics and values: these socio-technical conditions cannot easily be replicated in an effort to reproduce innovative potential (Lovell, 2004; Shove, 1998).

The second route for niche sustainable housing practices to influence the wider housing regime is through scaling up the existing small scale, one-off housing projects to industrial massproduction. This brings economies of scale to housebuilders, through standardisation of plans, materials and techniques, resulting in a profitable construction business. Straw bale building could be adopted by mainstream housebuilders as an economically rational, energy-efficient material, according to proponents (Amazon Nails, 2001). However, the models of sustainable housing discussed here are not necessarily practical for highvolume building. They rely heavily on manual labour (making the techniques well-suited for self-build and community projects) which is costly for commercial businesses, and they were developed in a context of cheaply available land and low density development, neither of which is applicable in the UK. Consequently, the scope for diffusion by this route is structurally limited.

The third way that sustainable housing niches can influence the regime is to translate ideas and practices from one to the other, adapting them for the different socio-technical setting of the mainstream building industry. For this translation process to occur effectively, a pre-existing condition of a crisis in the existing regime and an opportunity for niche practices to inform mainstream solutions is required - this can certainly be said to exist in the current need to develop low-carbon housing to mitigate climate change. Then the first option is for the mainstream conditions to open up opportunities for niche ideas to bridge the gap: government initiatives to encourage greener building standards represent this type of top-down adaptation of the regime to adopt niche practices. But as Shove (1998) reveals, there is a chasm of meaning between the differing socio-technical contexts between niche and mainstream. Incremental improvements in insulation standards, for example, do nothing to challenge the mainstream paradigm of housebuilding reliant upon finite supplies of fossil fuels which niche autonomous builders reject at the outset, and these conflicting perspectives prevent what might otherwise be seen as a purely technical transfer of knowledge. Therefore, the regulation-driven mainstream only adapts in an ad hoc and piecemeal manner, failing to transform the regime (Smith, 2007).

A second option for achieving a transfer from the niche is through the niche adapting itself to resemble the regime. This can be seen when green builders respond to regulatory pressures and strive to meet regime standards, in order to survive. This can take niche practices to the next level in terms of acceptability to regulators, familiarity with planning committees and so on, but there is the risk that is succeeding in some areas (e.g. meeting building regulations) can mean failing in others (e.g. affordability, accessibility). Examples might include the use of thermal mass to stabilise internal temperatures, shading from the sun, southfacing windows to capture solar gain, rainwater harvesting, microgeneration, etc. Modern methods of construction include using highly insulated pre-fabricated wall panels, built in a factory and assembled on site; these can be filled with straw, hempcrete 
and other recycled products, adapting niche material-use practices to mass-production. In terms of the growth of straw bale housing, these processes can be seen where professional builders construct quite mainstream-looking houses with straw bales, achieving large energy savings, but placing the building beyond the reach of those on low incomes. For example, Modcell (www.modcell.co.uk) are translating straw bale materials into a modern, mass-produced, factory-based building system, thereby overcoming many of the structural constraints of the low-impact housing niche as exemplified by the Canelo Project, but losing the social benefits.

A final option here is for intermediate projects such as BedZED in London, a low-energy high density inner city development. This was a "space where the practicability for volume housebuilders to operate more like green builders can be explored" and where "values, processes and circumstances actually bring contrasting socio-technical contexts together" for more effective learning than is achieved simply through regulations (Smith, 2007, pp. 439-40). This option remains to be explored for straw bale building in the UK.

\section{Building blocks and barriers to change}

This paper has presented a new analytical framework of 'grassroots innovations' which views community-led initiatives for sustainable development as strategic green niches with the potential for wider transformation of mainstream society. Applying this framework to a low-carbon, low-impact, communitybased sustainable housing initiative, it reveals that while the project achieves many sustainable housing outcomes in itself, it faces significant challenges in diffusing its ideas and practices beyond the niche and into wider society. The initiative was found to successfully achieve sustainable consumption, according to the New Economics indicators, through the use of local, recycled materials, socially inclusive and empowering construction techniques, and emphasis on reducing material throughput both in building and inhabitation of the dwellings, and in enabling selfbuild and autonomy from mainstream utility services. It presents a viable - if currently small scale - response to the need to mitigate climate change by reducing energy use, and adapt to the demands of changing climates. Furthermore, it presents an alternative system of housing provision to mainstream practices. However, despite aiming to spread their ideas through a variety of cognitive and social learning techniques, its influence on volume housebuilding to date has been minimal. It is clear that the innovations described here are radical versions of sustainable housing, not necessarily suitable for scaling up or widespread replication; however, the scope for niche lessons to be adopted by mainstream builders is greater.

These opportunities for translating niche practices and ideas into mainstream settings require certain political and social contexts to occur, and socio-technical transformation cannot be achieved by niches alone. Given the current need to develop lowcarbon sustainable housing, it can be seen that a tension exists in mainstream housing provision, and a supportive policy agenda could go a long way to helping capitalise on the learning and experience of green builders, in answering that need. Policy measures to support this transfer might include increasing regulatory pressure to increase building standards, so forcing mainstream builders to search for new techniques and technologies. Other top-down support of experimental green housing niches, is required, however, to bring the treatment of this innovative niche in line with the types of conditions routinely provided to technology innovators. This might be through funding for experimental developments, funding and support for institu- tionalised learning in the form of networks, resource-sharing and developing bridging institutions to allow niche actors access to policy arenas, and notice of upcoming opportunities to influence policy through consultations, etc.

In addition, a recognition of the innovative nature of niches at the policy level could lead to new approaches to governance of bottom-up community action for sustainable development. There may be lessons to be learned from the traditional innovation literature about diffusion, strategic niche management and nurturing innovation, which could usefully be applied to this new setting of the social economy. For instance, an innovation incubator approach might be an appropriate model for developing new low-carbon housing solutions, but might require a temporary relaxing of building regulations in order to allow experimentation with new techniques not currently recognised by regulations. In particular, an acceptance of the experimental need to fail - with the cost implications this brings - would be a radical new approach to managing community action. Alternatively, it may be that studying this new innovative site has lessons for innovation theory, in contributing a new branch of empirical innovation work on a previously neglected innovative capacity. Further empirical research is certainly needed on the development and potential of grassroots innovations to provide low-carbon solutions for sustainable development, and for policymakers to learn how to best harness those efforts.

\section{Acknowledgements}

The author is grateful to the UK's Economic and Social Research Council and Research Councils UK, for core funding at the University of East Anglia's Centre for Social and Economic Research on the Global Environment, and an Academic Fellowship, which has made this research possible. Thanks also to Athena and Bill Steen of the Canelo Project, who were generous with their hospitality, time and support. The anonymous referees provided helpful comments, which has strengthened the paper, although remaining omissions and deficiencies are the author's responsibility.

\section{References}

Amazon Nails, 2001. Information Guide to Straw Bale Building: For self-builders and the construction industry. Amazon Nails, Todmorden.

Berkhout, F., 2002. Technological regimes, path dependency and the environment. Global Environmental Change 12 (1), 1-4.

Boyle, D., 1993. What Is New Economics?. New Economics Foundation, London.

Burgess, J., Bedford, T., Hobson, K., Davies, G., Harrison, C., 2003. (Un)sustainable Consumption. In: Berkhout, F., Leach, M. Scoones, I. (Eds.), Negotiating Environmental Change: New Perspectives from social science. Edward Elgar, Cheltenham, pp. 261-291.

Canelo Project (n.d.). The Canelo Project: Connecting people, culture and nature. Canelo Project, Elgin.

Church, C., Elster, J., 2002. The Quiet Revolution. Shell Better Britain, Birmingham. Conrad, J. (Ed.), 1995. Eco-Villages and Sustainable Communities: Models for 21st Century Living. Findhorn Press, Findhorn.

Daly, H., Cobb, J., 1990. For the Common Good. Greenprint Press, London.

DCLG (Department for Communities and Local Government), 2007a. Building a greener future: policy statement. The Stationery Office, London.

DCLG (Department for Communities and Local Government), 2007b. Homes for the future: more affordable. More Sustainable the Stationery Office, London.

DCLG (Department for Communities and Local Government), 2008. The code for sustainable homes: setting the standard in sustainability for new homes. The Stationery Office, London.

DECC (Department of Energy and Climate Change), 2008. UK leads world with commitment to cut emissions by $80 \%$ By 2050 Press Notice ref $2008 / 3$, 16th October 2008 (DECC, London).

DEFRA, 2003. Changing Patterns: UK Government Framework for Sustainable Consumption and Production. Defra, London.

DEFRA, 2005. DEFRA and Social Enterprise: a Position Statement. Defra, London.

DEFRA, 2005b. Delivering sustainable development at community level $<w w w$. sustainable-development.gov.uk/delivery/global-local/community.htm $\rangle$ accessed 24 October 2005 
DEFRA, 2007. A Framework for Pro-Environmental Behaviours. DEFRA, London.

DETR (Department of the Environment, Transport and the Regions), 1999. A Better Quality of Life: a Strategy for Sustainable Development for the United Kingdom. DETR, London.

Dobson, A., 2003. Citizenship and the Environment. Oxford University Press, Oxford.

Douthwaite, R., 1992. The Growth Illusion. Green Books, Bideford, UK.

DTI (2005). Innovation 〈www.innovation.gov.uk> accessed 24 October 2005

Ekins, P. (Ed.), 1986. The Living Economy: A New Economics in the Making. Routledge, London.

Energy Saving Trust, 2003. The Hockerton Housing Project Energy Efficiency Best Practice in Housing, New Practice Profile 119. Energy Saving Trust, London.

Energywatch, 2008. Cheapest energy bills not the same as affordable bills, says energywatch [press release, 20 March 2008. <http://www.energywatch.org. uk $>$.

Environment Agency, 2008. Water Neutrality 〈http://www.environment-agency. gov.uk/subjects/waterres/287169/1917628/?lang=_e $\rangle$ accessed 31 March 2008.

Fairlie, S., 1996. Low-Impact Development: Planning and People in a Sustainable Countryside. Jon Carpenter Publishing, Charlbury.

Fine, B., Leopold, E., 1993. The World of Consumption. Routledge, London.

Hacker, J., Belcher, S., Connell, R., 2005. Beating The Heat: Keeping UK Buildings Cool in a Warming Climate UKCIP Briefing Report. UKCIP, Oxford.

Hart, K., n.d. A sampler of alternative homes: approaching sustainable architecture VHS, (Crestone Co., Hartworks) available from 〈http://www.greenhomebuild ing.comwww.greenhomebuilding.com $>$.

Henderson, H., 1995. Paradigms in Progress: Life beyond Economics. BerrettKoehler Publishers, San Francisco (originally published 1991).

HM Government, 2005. Securing the future: delivering UK sustainable development strategy. The Stationery Office, Norwich.

Hulme, M., Jenkins, G., Lu, X., Turnpenny, J., Mitchell, T., Jones, R., Lowe, J., Murphy, J., Hassell, D., Boorman, P., McDonald, R., Hill, S., 2002. Climate change scenarios for the United Kingdom: The UKCIP02 Scientific Report. Tyndall Centre for Climate Change Research, UEA, Norwich

Jackson, T., 2007. Consuming Paradise? Towards a social and cultural psychology of sustainable consumption. In: Jackson, T. (Ed.), The Earthscan Reader in Sustainable Consumption. Earthscan, London, pp. 367-395.

Jackson, T., 2009. Prosperity without Growth? The transition to a sustainable economy. Sustainable Development Commission, London.

Jacobs, J., 1984. Cities and The Wealth of Nations: Principles of Economic Life. Random House, London.

Law, B., 2005. The Woodland House. Permanent Publications, East Meon, Hampshire.

Lovell, H., 2004. Framing sustainable housing as a solution to climate change. Journal of Environmental Policy and Planning 6 (1), 35-55.

Lutz, M., 1999. Economics for the Common Good: Two Centuries of Social Economic thought in the Humanistic Tradition. Routledge, London.

Lynas, M., 2007. Can shopping save the planet?. The Guardian G2, 4-7.

Maniates, M., 2002. Individualization: plant a tree, buy a bike, save the world?. In: Princen, T., Maniates, M., Konca, K. (Eds.), Confronting Consumption. MIT Press, London, pp. 43-66.

Max-Neef, M., 1992. Development and human needs. In: Ekins, P., Max-Neef, M. (Eds.), Real-Life Economics: Understanding Wealth Creation. Routledge, London, pp. 197-213.
Meadows, D.H., Meadows, D.L., Randers, J., Behrens, W.W., 1972. The Limits to Growth. Universe Books, New York.

Mulgan, G., Ali, R., Halkett, R., Sanders, B., 2007. In and Out of Sync: The Challenge of Growing Social Innovations. NESTA, London.

O'Riordan, T., 2001. Globalism, Localism and Identity: Fresh Perspectives on the Transition to Sustainability. Earthscan, London.

Pearson, D., 1989. The Natural House Book: Creating a Healthy, Harmonious and Ecologically Sound Home. Conran Octopus, London.

Porritt, J., 2003. Redefining prosperity: resource productivity, economic growth and sustainable development. Sustainable Development Commission, London.

Rip, A., Kemp, R., 1998. Technological change. In: Rayner, S., Malone, E.L. (Eds.), Human Choice and Climate Change, Vol. 2. Battelle Press, Columbus.

Røpke, I., 2009. Theories of practice: new inspiration for ecological economic studies of consumption. Ecological Economics 68 (10), 2490-2497.

Sanne, C., 2002. Willing consumers - or locked-in? Policies for a sustainable consumption. Ecological Economics 42, 273-287.

Schumacher, E.F., 1993. Small Is Beautiful: A Study of Economics as if People Mattered. Vintage, London (first published 1973).

SDC (Sustainable Development Commission), 2006. Stock Take: Delivering Improvements in Existing Housing. SDC, London.

Seyfang, G., 2004. Consuming values and contested cultures: a critical analysis of the UK strategy for sustainable consumption and production. Review of Social Economy 62 (3), 323-338.

Seyfang, G., 2005. Shopping for sustainability: can sustainable consumption promote ecological citizenship?. Environmental Politics 14 (2), 290-306.

Seyfang, G., 2008. The New Economics of Sustainable Consumption: Seeds of Cange. Palgrave Macmillan, Basingstoke.

Seyfang, G., Smith, A., 2007. Grassroots innovations for sustainable development: towards a new research and policy agenda. Environmental Politics 16 (4), 584603.

Shove, E., 1998. Gaps, barriers and conceptual chasms: theories of technology transfer and energy in buildings. Energy Policy 26 (15), 1105-1112.

Shove, E., 2004. Changing human behaviour and lifestyle: a challenge for sustainable consumption?. In: Reisch, L., Røpke, I. (Eds.), The Ecological Economics of Consumption. Edward Elgar, Cheltenham, pp. 111-131.

Smith, A., 2007. Translating sustainabilities between green niches and sociotechnical regimes. Technology Analysis \& Strategic Management 19 (4), 427-450.

Southerton, D., Chappells, H., Van Vliet, V., 2004. Sustainable Consumption: The implications of Changing Infrastructures of Provision. Edward Elgar, Aldershot.

Steen, A., Steen, B., 2001. The Beauty of Straw Bale Homes. Chelsea Green, Totnes.

Steen, A., Steen, B., Bainbridge, D., Eisenberg, D., 1994. The Straw Bale House. Chelsea Green, Totnes.

Vale, B., Vale, R., 2000. The New Autonomous House: Design and Planning for Sustainability. Thames and Hudson, London.

Van Vliet, B., Chappells, H., Shove, E., 2005. Infrastructures of Consumption: Environmental Innovation in the Utility Industries. Earthscan, London.

Wackernagel, M., Rees, W., 1996. Our Ecological Footprint: Reducing Human Impact on the Earth. New Society Publishers, Philadelphia.

White, N. (Ed.), 2002. Sustainable Housing Schemes in the UK. Hockerton Housing Project, Hockerton, Notts.

Wrench, T., 2001. Building a Low-Impact Roundhouse. Permanent Publications, East Meon, Hampshire. 